\title{
Correction: Disruption of gap junctions attenuates acute myeloid leukemia chemoresistance induced by bone marrow mesenchymal stromal cells
}

\author{
Farah Kouzi ${ }^{1,2,3} \cdot$ Kazem Zibara $\mathbb{1}^{3,4} \cdot$ Jerome Bourgeais ${ }^{1,2,5} \cdot$ Frederic Picou $^{1,2,5} \cdot$ Nathalie Gallay ${ }^{1,2,5} \cdot$ \\ Julie Brossaud $^{6}$. Hassan Dakik (10) ${ }^{1,2} \cdot$ Benjamin Roux ${ }^{1,2,5} \cdot$ Sophie Hamard ${ }^{1,2} \cdot$ Louis-Romee Le Nail $^{7} \cdot$ Rita Hleihel $^{8,9}$. \\ Amelie Foucault ${ }^{1,2,5} \cdot$ Noemie Ravalet $^{1,2,5}$. Florence Rouleux-Bonnin ${ }^{1,2} \cdot$ Fabrice Gouilleux $^{1,2} \cdot$ Frederic Mazurier $^{1,2}$. \\ Marie C. Bene ${ }^{10} \cdot$ Haidar Akl ${ }^{3,4} \cdot$ Emmanuel Gyan $^{1,2,11} \cdot$ Jorge Domenech $^{1,2,5} \cdot$ Marwan El-Sabban $^{8}$. \\ Olivier Herault $\mathbb{1}^{1,2,5}$
}

Published online: 7 November 2019

(c) The Author(s) 2019. This article is published with open access

\section{Correction to: Oncogene}

https://doi.org/10.1038/s41388-019-1069-y

The original version of this article omitted the following from the Acknowledgements:

This research was also supported by grants to KZ (UL and L-CNRS).

This has now been corrected in both the PDF and HTML versions of the Article.
Olivier Herault

olivier.herault@univ-tours.fr

1 CNRS ERL7001 LNOx "Leukemic Niche \& Redox Metabolism", Tours, France

2 EA7501 GICC, University of Tours, Faculty of Medicine, Tours, France

3 PRASE, DSST, Lebanese University, Beirut, Lebanon

4 Biology Department, Faculty of Sciences, Lebanese University, Beirut, Lebanon

5 Department of Biological Hematology, Tours University Hospital, Tours, France

6 Department of Nuclear Medicine, Bordeaux University Hospital, Pessac, France
Open Access This article is licensed under a Creative Commons Attribution 4.0 International License, which permits use, sharing, adaptation, distribution and reproduction in any medium or format, as long as you give appropriate credit to the original author(s) and the source, provide a link to the Creative Commons license, and indicate if changes were made. The images or other third party material in this article are included in the article's Creative Commons license, unless indicated otherwise in a credit line to the material. If material is not included in the article's Creative Commons license and your intended use is not permitted by statutory regulation or exceeds the permitted use, you will need to obtain permission directly from the copyright holder. To view a copy of this license, visit http://creativecommons. org/licenses/by/4.0/.
7 Department of Surgical Orthopedia, Tours University Hospital, Tours, France

8 Department of Anatomy, Cell Biology, and Physiological Sciences, Faculty of Medicine, American University of Beirut, Beirut, Lebanon

9 Department of Internal Medicine, Faculty of Medicine, American University of Beirut, Beirut, Lebanon

10 Department of Biological Hematology, Nantes University Hospital, CRCINA, Nantes, France

11 Department of Hematology and Cell Therapy, Tours University Hospital, Tours, France 